\title{
Lexis
}

Journal in English Lexicology

$7 \mid 2012$

Euphemism as a Word-Formation Process

\section{Euphemism and Language Change: The Sixth and Seventh Ages}

\section{Kate Burridge}

\section{(2) OpenEdition}

\author{
Journals
}

Electronic version

URL: http://journals.openedition.org/lexis/355

DOI: $10.4000 /$ lexis.355

ISSN: 1951-6215

\section{Publisher}

Université Jean Moulin - Lyon 3

Electronic reference

Kate Burridge, "Euphemism and Language Change: The Sixth and Seventh Ages », Lexis [Online],

7 | 2012, Online since 25 June 2012, connection on 30 April 2019. URL : http://

journals.openedition.org/lexis/355; DOI : 10.4000/lexis.355

\section{(c) (1) (9)}

Lexis is licensed under a Creative Commons Attribution-NonCommercial-NoDerivatives 4.0

International License. 


\title{
Euphemism and Language Change: The Sixth and Seventh Ages
}

Kate Burridge ${ }^{1}$

\begin{abstract}
No matter which human group we look at, past or present, euphemism and its counterpart dysphemism are powerful forces and they are extremely important for the study of language change. They provide an emotive trigger for word addition, word loss, phonological distortion and semantic shift. Word taboo plays perpetual havoc with the methods of historical comparative linguistics, even undermining one of the cornerstones of the discipline - the arbitrary nature of the word. When it comes to taboo words, speakers behave as if there were a very real connection between the physical shape of words and their taboo sense. This is why these words are so unstable and why they are so powerful. This paper reviews the various communicative functions of euphemisms and the different linguistic strategies that are used in their creation, focusing on the linguistic creativity that surrounds the topic of 'old age' in Modern English (Shakespeare's sixth and seventh ages). And since personal names form such a special case of word taboo, some consideration will also be given to the ancient and modern perspective of naming.
\end{abstract}

Key words: taboo - euphemism - dysphemism - orthophemism - politically correct language - expressive creativity - names - aging

${ }^{1}$ Many thanks to Keith Allan for casting his expert eye over this paper. As always I am very grateful for his input. 


\section{Introduction - the functions of euphemism}

I need first to explain my use of the labels euphemism, dysphemism and orthophemism. X-phemism (the union set of these 'phemisms') is primarily determined from evaluating expressions within the particular context in which they are uttered. Given there is such complexity and variety of opinions and attitudes, we are unlikely to ever find uniformity of judgement between speakers of even very similar social backgrounds. There is never 'Everyman's euphemism' or 'Everyman's dysphemism'. However, it would ignore reality to pretend that ordinary people do not perceive expressions to be somehow intrinsically X-phemistic: terms for 'die' such as pass away and sleep are euphemistic, whereas croak and peg out are not. Milwood-Hargrave [2000] is a British survey where participants were asked to respond to the perceived 'strength' of twenty-eight swearwords. No context was provided; yet, participants were clear about the severity of these words and the researchers were able to put together a broad topography of swearwords across all groups. Modern dictionaries also treat expressions as if they were inherently dysphemistic when they indicate offensive connotations of particular entries. The Encarta World English Dictionary recognizes three degrees of offensiveness: 'insulting', 'offensive', and 'taboo'. Similarly, those who compile dictionaries of euphemisms and dysphemisms, such as Ayto (1993) and Green (1996), base their collections on the prejudiced social attitudes to the situation in which they believe a given expression is uttered. This sort of 'sensitive handling' employs a type of good etiquette gauge by which is determined the X-phemistic value of an expression without reference to the context of use (cf. the 'middle class politeness criterion' in Allan and Burridge [2006: 33]). Like Allan (this volume), this is also the measure I will be assuming here where context is not specified.

The literature of euphemism shows that examples can be wide-ranging: medieval Dutch physicians would write of figs in the secret passage to denote "piles"; the 19th century Victorian moral code created negative words such as inexpressibles, unmentionables and unhintables so that those in polite society could avoid uttering legs, trousers and underclothing; some people (including the current author) still say crumbs instead of Christ; many newspapers still print $c^{* * *}$ and $f^{* * *}$; politicians speak of community charges, levies or even voluntary contributions rather than of taxes or tolls; prairie oysters, mountain oysters and fry sound more appetizing than calf's testicles; lemon fish and flake far tastier than shark; companies downsize, rightsize, or implement an RIF (Reduction In Force) through targeted voluntary separation or involuntary resignation; the push for non-sexist usage has rendered words like chairman and actress taboo for some people; and so on.

Very broadly, euphemisms are sweet-sounding, or at least inoffensive, alternatives for expressions that speakers or writers prefer not to use in executing a particular communicative intention on a given occasion. Within this all-embracing job description, we can identify at least six different (though frequently overlapping) tasks that euphemisms perform. As will become clear, these have a bearing both on the types of euphemism used (the linguistic strategies drawn on to create expressions) and on their career span (their semantic stability and durability). Euphemisms fulfilling the first two functions maintain a low profile; it is all about obscuring and disguising disagreeable reality. Their life cycle can be very different from the other more attention seeking euphemisms. Here speakers or writers are typically doing something clever or humorous with the language; their creations refuse to take the back seat normally 
reserved for the regular face-saving euphemisms (to draw on Dwight Bolinger's image for anaphora; 1980: 96). The life expectancy of these euphemisms is very often short.

\subsection{The protective euphemism - to shield and to avoid offense}

Euphemisms are characterized by avoidance language and evasive expression. We create them when we are faced the tricky problem of how to talk in different contexts about things that for one reason or another we would prefer not to speak of unrestrainedly in the prevailing context. In this primary function, euphemisms are verbal escape hatches created in response to taboos. These include the usual suspects private parts, bodily functions, sex, anger, dishonesty, drunkenness, madness, disease, death, dangerous animals, fear, God and so on — as Adams and Newell [1994: 12] describe 'an infinite variety of things that go bump in the night'.

Traditionally, much was made of the difference between conditional and unconditional (or absolute) taboo. When the word first entered English in the $18^{\text {th }}$ century from Tonga, it referred to conduct believed to be dangerous to certain individuals or to the society as a whole. In this context, violations of taboos were expected to have dire consequences and euphemism was literally a matter of life or death. Taboo Polynesian-style was said to absolute - a 24-hour a day, round the clock affair. However, the reality is no taboo holds for all people, times and contexts (Allan and Burridge [2006: Ch. 1]). Moreover, Old Polynesia also had evidence of the sorts of selective taboos on bad manners with which readers of this volume experience in their everyday lives; in other words, social sanctions placed on behaviour that is regarded as distasteful or at least impolite within a given social context. The taboos of social convention in the Western world rest on traditions of etiquette and are therefore set by social parameters such as age, sex, education, social status and the like. They are sometimes observed in private, though they are strongest in the public domain where euphemism becomes the polite thing to do and dysphemism little more than the breaking of a social convention. It is the untimeliness that causes the offense.

There will always be significant differences between individual societies and individuals within those societies with respect to the degree of tolerance shown towards any sort of taboo-defying behaviour - much will depend on the values and belief systems at the time. Taboo is also dynamic, and notions about what is forbidden will change, sometimes dramatically, across cultures and across time. The Bowdlerites of the $19^{\text {th }}$ century targeted profanity and sexual explicitness and this triggered the progressive sanitising of a range of works, including the Bible. Their activities seem excessive according to today's sensitivities. Yet, works of this period also appear remarkably uninhibited at times. The police-court reports of Charles Adam Corbyn from the 1850s, for example, abound descriptions of local residents that make a modern reader's toes curl: Mr Ninivian Stewart is portrayed as 'a long-nosed, lank-jawed, hypocritical-looking shoemaker'; Robert Tindal 'a hen-pecked old man'; Leah Harris 'a handsome Jewess'; Miss Mary Anne Walsh 'a middling aged spinster'; Mrs Elizabeth Hilton 'a tall, powerful woman, whose face outvies in colours those of a round of spiced beef'; Donald M'Kenzie (or Darkey Ken) as 'an ogre-like Negro, of the dirtiest black colour imaginable'. Since the 1980s, gender, sexuality, disability and race have become so highly-charged that speakers will shun anything that may be interpreted as discriminatory or pejorative. These new taboos make sexist, racist, ageist, religionist, etc. language not only contextually dysphemistic, but also legally so (cf. Allan and Burridge [2008]). These -IST taboos have surpassed in significance irreligious profanity, 
blasphemy and sexual obscenity, against which laws have been relaxed ${ }^{2}$.

\subsection{The underhand euphemism - to mystify and to misrepresent}

There is a sense in which all euphemism is dishonest. No euphemism says it how it is - in a given context, something tabooed can be acceptably spoken of using a euphemism but not using a direct term. However, the euphemistic vocabulary of language varieties such as military, political and medical jargons adds additional dimensions of guile and secrecy to the disguise. Here euphemism is used, not so much to conceal offense but to deliberately disguise a topic and to deceive. This is the sort of doublespeak that turns death into a substantive negative patient care outcome, a diagnostic misadventure of the highest magnitude or a terminal episode; dying into terminal living and killing into the unlawful [or] arbitrary deprivation of life.

Examples such as these have lead to deprecation of the term 'euphemism' itself. For many, it has become a pejorative label attached to language believed to be value-laden and deliberately obfuscatory; in other words, jargon that is intended to befuddle and to disguise ordinary and inconvenient facts, or as George Orwell once famously described, expressions 'designed to make lies sound truthful and murder respectable, and to give an appearance of solidity to pure wind' (Politics and the English Language, 1946). It is very much an Orwellian-inspired view of euphemism that has come to dominate public discourse. Impatient with the pretence that sweeter words might produce a sweeter world, many also grow concerned at what appear to be attempts to manipulate their thoughts and opinions. And though public opinion is not as easily manipulated as Orwell's Newspeak suggests, studies by researchers such as Elizabeth Loftus show that loaded language can indeed work to influence memory and perception. Expressions such as soft skin target, surgical strikes, collateral damage and friendly fire also help to minimize feelings of responsibility. They play down the slaughter of human beings and also create psychological distance between the perpetrators and their actions.

A type of dishonest euphemism also flourishes in domains associated with activities in conflict within the more established sectors of society. Within the antilanguages of 'underworld' subcultures ('the languages of the antisociety'; Halliday [1978: 171]), we see euphemistic synonyms that have a function in concealing the nefarious nature of whatever they designate, with the express purpose of keeping outsiders in the dark. The following is a handful of examples from the over 2, 300 street terms that refer to illicit drug types or drug activity (taken from a glossary compiled by the White House Office of National Drug Control Policy): get snotty ("to use heroin"); candy sticks ("marijuana cigarettes laced with powdered cocaine"); gym sticks ("steroids used by athletes"); hugs and kisses ("methamphetamine and methylenedioxymethamphetamine" or "MDMA"); lipton tea / lemonade ("poor quality drugs"); klingons ("crack addicts"). The high turnover rate of this vocabulary means that these terms may soon be passé; the need to maintain secrecy ensures that as soon as a term's cover is blown, it has to be replaced. The linguistic disguise need not always be to conceal the disreputable, however. The mercantile code of Dutch fishermen reverses syllables and also sometimes words to

\footnotetext{
2 In Australia, sports players are never charged for foul language on the field, unless the complaint involves race discrimination or vilification. When a footballer was disciplined for calling Aboriginal player Michael Long 'black cunt' during an Australian Rules match, the reports and re-reports of the incident made no reference to the use of cunt. It was the racial abuse that triggered the uproar, and the incident gave rise to a new code of conduct against racial vilification both on and off the sporting oval (Scutt [2002]).
} 
disguise expressions so that other fishermen won't uncover their secrets; trade jargons, such as Romani, can also work as a secret code to conceal information from customers or any would-be competitors on the outside (cf. Burridge and Allan [1998]).

\subsection{The uplifting euphemism - to talk up and to inflate}

In their ability to place whatever it is they designate in a favourable light, many euphemisms are simply alternatives for expressions speakers prefer not to use on a given occasion. Clause 28 of the Melbourne Metropolitan Planning Scheme makes several references to the accommodation of stationary vehicles. ${ }^{3}$ The author presumably believed that this phrase has more favourable connotations than either parking places or car spaces; in fact these are probably dispreferred simply because they do not have the Latinate ring of bureaucratese. Such examples are comparable to the upgrade of potholes to pavement deficiencies, bottlenecks to localised capacity deficiencies and the promotion to Chicken-Ham à la Princesse of a recipe involving canned cream of chicken soup with cubed spam and evaporated milk.

Clearly, with euphemisms of the uplifting kind we again collide with jargon, the language peculiar to a trade, profession or some other group. The hamburger industry's use of the term autocondimentation as opposed to precondimentation is an economical way of distinguishing a client's right to salt his/her own hamburger. It is certainly not necessary to use these terms in order to get the meaning across, so why use them? The answer is, of course, that they confer on the hamburger industry a certain dignity. The dignity comes from the Greek or Latin roots of the words used (the Graeco-Latinate lexicon), because they are reminiscent of such prestigious jargons as Legalese and Medicalese. When jargons use this kind of highfalutin language it also achieves a doublewhammy by also mystifying and intimidating the clientele. The second motivation therefore is shared with the dishonest euphemism; namely, the exclusion of outsiders. This exclusion is in part designed to intimidate the populace through mystification.

Taboo can be involved here. The jargon of the funeral industry is excessively euphemistic precisely because it deals with death. Legalese is euphemistic when it has to handle indecorous matters like indecent exposure of the person [where person = "penis"]. When the subject matter does not obviously concerns taboos, however, we reach the outer bounds of euphemism (cf. Allan and Burridge [1991: Ch. 9]). The following notice to householders from the City of Fitzroy in Melbourne, Australia, contains some quintessential features of ponderous legalese: 'Refuse and rubbish shall not be collected from the site or receptacles thereon before the hour of $8.00 \mathrm{am}$ or after the hour of $6.00 \mathrm{pm}$ of any day'4. It would be stretching credulity to say that council rubbish collection is a matter of taboo. This memo contains expressions that presumably have more pleasing connotations than alternative ways of speaking simply by virtue of their being jargon.

\subsection{The provocative euphemism - to reveal and to inspire}

Euphemisms are not always 'linguistic fig-leaves'. As Allan describes (this volume) many are more like 'diaphanous lingerie'; they conceal only as little as to be all the more

\footnotetext{
3 Many thanks to Pia Herbert for supplying us with the relevant passages from the Melbourne Metropolitan Planning Scheme; cf. Börjars and Burridge [2001] for further discussion.

${ }^{4}$ Thanks again to Pia Herbert for this gem.
} 
titillating. In the mouth or pen of a political satirist, for example, euphemisms are deliberately provoking. George Orwell's Animal Farm is at one level a children's story and, at another, a blistering political satire. Such writers exploit euphemism to publically expound taboo topics. The 'Camera Song' by Grit Laskin (to the tune of 'Three Drunken Maidens') is a modern bawdy allegory where, as in other examples of euphemism as art, the author makes the pretence of adhering to the middle class politeness criterion, even though the doublespeak text has tabooed denotations. Such artsy euphemisms are designed to excite and arouse; and the best of them succeed (Allan and Burridge [1991: Ch. 10]). As Epstein once remarked, 'the best pornographer is the mind of the reader' [1985: 64].

PC-inspired euphemism is not so very different; it aims not to disguise or conceal unpleasant reality, but to help remove the stigma of negative social stereotypes by compelling its audience to go beyond the simple content of the message and challenge prejudices embodied in language (cf. Allan and Burridge [2006: Ch. 4]. 'Generic' she is intended to jar - by drawing attention to form, it forces us to sit up and take notice. The use of double pronouns $s /$ he and him/her can be deliberately clumsy, the dysphemism of a distracting style an effective way of getting a message across. Politically correct terms also deliberately highlight certain aspects of a group's identity. When members of the black community campaigned to be called African Americans, it was to emphasize not genetics or colour, but the historical roots of a group that forms part of the USA, thus bringing the name into line with those of other ethnic minorities, such as Japanese Americans and Italian Americans. Many people probably remain oblivious to the political message. For many, the political correctness protocol is the dessicated remnant of old knowledge and opinion; it becomes a matter mouthing the right-sounding words, consistent with the political correctness ethos.

Clearly, with provocative euphemisms there is more involved than straightforward politeness and the maintenance of face. However, even the more mainstream euphemisms that function as face-saving devices often do more than cover up abhorrent reality; euphemisms for death invoke different points of view such as death as a journey (pass away), or the consolation of death as the beginning of new life (go to a better place) (cf. Jamet [2010]). The image they offer is one of consolation.

\subsection{The cohesive euphemism - to show solidarity and to help define the gang}

Taboos are among the common values that link the people of a community together; they become a sign of social cohesion. To outsiders, many are perplexing and seem silly. Even those on the inside are often unaware of the reasons that might have led to their establishment. Original meaning gives way to unthinking routine; fear and respect become lost in social convention. And what one group values, another comes to scorn. Shared taboos and the rites and rituals that accompany our euphemistic behaviour increase group identity through feelings of distinctiveness; they strengthen the social fabric.

There is another sense in which euphemisms can work as in-group trademarks. Depending on the context, many examples of the euphemistic nomenclature in the preceding sections are used among people who have a common work-related or recreational interest; they perform the additional function of reinforcing and displaying group identity, especially when directed against outsiders. Where the language identifies shared experiences that are taboo, as in the case of hospital staff who have to 
manage disease, dying and death on a daily basis, euphemisms make the job easier to bear by disguising unpleasant reality, but also by creating rapport. Where the activities are marginal, unofficial or illegal, there is the added motivation of secrecy. Sometimes it is simply a matter of identifying activities, events and objects that have become routine for those involved, and like slang and jargon more generally, this is preferred language by virtue of it serving as a 'clique' or in-group recognition device. In this instance, we are again on the periphery of euphemism proper.

\subsection{The ludic euphemism - to have fun and to entertain}

It is also clear that many euphemisms are created largely to amuse. It is unlikely that the $18^{\text {th }}$ century expression the miraculous pitcher, that holds water with the mouth downwards for "vagina" was ever anything but a bit of fun (cf. Grose [1783]). David Crystal [1998: 183] demonstrates the ubiquity and creativity of language play among ordinary language users, and points out that 'when children arrive in school, their linguistic life has been one willingly given over to language play'; this continues throughout their lives. In the case of euphemistic substitutions for the '-IST-language' described earlier, it is doubtful whether expressions such as person with hard to meet needs (= "serial killers") or the differently pleasured (= "sado-masochists") were ever more than simply humorous inventions. During the 1990s, the PC debate provided an abundance of lampooning fodder for many comedians. Melbourne comic Wendy Harmer confronted her 'unthinking lookism' and called for an 'Appearance Vilification Bill' and affirmative action within the modelling industry (The Age Good Weekend April 29, [1995: 16]). Her aim was that by the year $200020 \%$ of all models were to have big noses and flabby stomachs. Ludic euphemisms form a part of our everyday verbal play and, as Allan (this volume) shows, the manipulation of language that speakers display is remarkably inventive at times - ordinary speakers take ordinary sounds and letters, words and phrases and put them to extraordinary uses in the expressions they construct.

\section{Creating euphemisms - 'old age'}

And one man in his time plays many parts, His acts being seven ages. At first the infant, Mewling and puking in the nurse's arms; Then the whining school-boy, with his satchel And shining morning face, [...]. And then the lover, Sighing like furnace, with a woeful ballad Made to his mistress' eyebrow. Then a soldier, full of strange oaths, [...] And then the justice, In fair round belly with good capon lin'd, With eyes severe [...] The sixth age shifts Into the lean and slipper'd pantaloon, With spectacles on nose and pouch on side, [...] Last scene of all, That ends this strange eventful history, Is second childishness and mere oblivion. Sans teeth, sans eyes, sans taste, sans every thing. Shakespeare, As You Like It [II. vii] 
Clearly, aging is a matter of taboo, especially in modern times. There are certain things in life speakers and writers would rather not evoke too vividly and growing old is one of them. Digitally altered images of designer bodies make the reality of our own aging bodies hard to bear. In a virtual world of botox, boosted breasts and tummy tucks, postmenopausal women can now give birth and fresh medical breakthroughs rescue people daily from death. Perpetual well-being and ever-lasting youth seem well within our grasp. Big companies who profit from modern health preoccupations are happy to feed the fairy tale. The verbal vanishing creams and linguistic makeovers are all part of the pretence. Ironically, the increased life expectancy that modern medicine now affords us adds to the negative perceptions of old age. These days aging is disparaged also from the point of view of the burden that old people place on society at large - a longer life means more exposure to disease and ill-health and this means greater encumbrances on relatives and on already stretched resources.

Euphemisms for 'old age' are not simply in response to taboo, however, and the examples given in each section below range across all the six functions outlined earlier. Often these collide to support the formation of expressions and many of the euphemisms are multifunctional. For example, in Australian hospitals, we find reference to crumbles "the frail and elderly at death's door"; grots "derelicts and alcoholics"; vegetables "unresponsive or comatose patients"; diagnoses like F.L.K. "Funny Looking Kid"; G.O.K. "God Only Knows"; and someone who has passed through the valley of tears is simply cactus or "dead". This is just a small sample of hospital slang (given the rapid turnover of slang, these examples might well be outdated by now); and, depending on context, it can be described as euphemistic, dysphemistic or simply descriptive, in other words, orthophemistic. Clearly, the language is used to distance hospital staff from the sickness and death around them, and helps to blot out the awareness of their own vulnerability and that of their co-workers. There is also much playfulness here. I can report from first hand experience that frivolity is extremely common among staff in aged care facilities when talking to each other. For people who have to deal with the dying and with death everyday, this seeming irreverence for human life makes such work much easier to bear. Levity towards what is feared is widely used as means of coming to terms with the fear, by downgrading it. At the same time, these expressions also identify activities, events, and objects that have become routine for those involved and have an important function in creating rapport in the work environment. Gordon [1983] claims that this is the only motive for the existence of such slang, but my experience of hospital expressions does not support him. There is more at stake than simply defining the gang.

\subsection{The linguistic strategies}

The many different linguistic devices used in the formation of euphemisms fall into three overarching mechanisms: analogy (generalization of forms to new situations), distortion (modification of forms) and borrowing (incorporation of forms from elsewhere). The function of a euphemism will have a bearing on which strategy is used. Bold imagery, irony, rhyme and sound association are some of the forces behind the creation of the expressions that seek to grab; these euphemisms motivate lexical novelty. However, if the aim is to put up a smokescreen, then hypernymy and metonymy are among the favourites.

The examples provided here are drawn entirely from English, though they illustrate universal processes. All of these devices figure strongly in the formation of X-phemism 
across the languages of the world to a greater or lesser extent. I should also emphasize that none of these processes are mutually exclusive, and many examples fall at the same time into a number of different categories. For instance, euphemistic expressions such as at the evening of one's days and the autumn or the winter of one's life for 'old' are metaphorical, long-winded and hyperbolic, as are the expressions mutton dressed up as lamb and long in the tooth. No spring chicken is an example of metaphor and understatement. Past it illustrates a general-for-specific euphemism and also omission (leaving out one's prime from the end of the phrase).

\subsubsection{Analogy}

There are many strategies that do not lead to the creation of new forms in the language, but fashion novel euphemisms from already existing vocabulary. The process is generally one of analogy; in this case it involves a transfer of meaning from one given context to another. It could also be described as a type of internal borrowing, because speakers are taking expressions from one part of the language and incorporating them elsewhere.

Metaphor is the most common of these processes. The taboo topic is paired up with a pleasurable notion, sometimes establishing chains of figurativeness, almost in the manner of an overarching megametaphor (an especially common device for artsy euphemisms; Allan and Burridge [1991: Ch. 10]. Those who find themselves in their riper years or at a ripe old age might also be described as mellow; in other words, "soft and fully flavoured from ripeness". They are also mature or matured (in some cases ultra-mature; one dating website describes 'ultra-mature lovers' as men and women falling somewhere between 50 years and 115 years $^{5}$ ). Maturity is a positive concept; it implies that person is fully developed in body or mind. This is something we would presumably reach in our late teens, but taboo stretches it so that it becomes something much older. A famous feature of the World Fair in New York in the 1964-65 was something called the Dynamic Maturity Pavilion - a garden with benches where those of mature years could rest. Expressions like seasoned and seasoned citizen have something of the same notions of fulfilment and maturity - with perhaps the additional associations of a tasty dish. Still using the same 'ripeness' imagery are expressions such as the golden years and those golden agers who inhabit them. These have now well and truly had their day, as have expressions such as sunset years and twilight years. The geriatric hospital I worked in for some time was called Sunset Home. Other homes (another nice euphemism) around that time (the 1980s) had similar names: Twilight Home, Eventide Home and so forth. But the imagery is now tired. These days rest homes sport up-beat names full of promise: Pine View Gardens, Enhance, Le Grand, Nirvana, Perpetua-In-The-Pines, Primelife to name just a few close to where I live.

In Allan and Burridge [2006: Ch. 4], we described various kinds of whole-for-part (or general-for-specific) and part-for-whole substitutions. This terminology we felt was more transparent than the traditional 'synecdoche' and 'metonymy', the interpretations of which are surprisingly various. Many substitutions involve expressions that refer to something that is conceptually linked somehow with the tabooed sense. Vagueness is what speakers seek in a euphemism, especially where face-saving is the main motivation, and often the replacements are involve a high level of abstraction. Synecdochic subterfuges such as past it substitute very general words in place of more

\footnotetext{
${ }^{5}$ http://www.tagged.com/ultramaturelovers; accessed $4^{\text {th }}$ May 2011.
} 
explicit terms, in this case one's prime (compare doing it for "sexual intercourse"). People (usually women) of a certain age are assumed to be in around 'middle age' (wherever that might be); yet the word certain renders the message indistinct. (You could compare women in a certain condition "pregnant" or people with a certain disease "venereal disease, usually syphilis".) Aged care institutions are described simply as homes, hostels, houses, cottages, villages, residences and so forth. Many of these general-for-specific euphemisms involve the sort of linguistic restraint that is usually described as understatement. A special type of understatement is litotes, where the affirmative is expressed in terms of the denial of its opposite, a favourite strategy of bureaucrats (specifically the not in/un - strategy, as in a not insignificant amount and not unnaturally). The confusion arising from the negative of the contrary here mitigates the force of the utterance; it is well established in the psycholinguistic literature that multiple negatives pose difficulties for cognitive processing6. Examples of litotes in the context of old age include not youthful, not in one's first youth, no spring chicken. Some of us are not as young as we used to be - but then neither are babies.

Part-for-whole euphemisms are demonstrated in expressions such as grey hairs, white hairs "old age", greying "aging", go grey, turn white "to age" and greybeard "old man". Such expressions would more usually be used in polite reference to males for whom the distinguished look that comes with the banker's rinse is a more desirable attribute. The greying of Australia for some time became almost a catch phrase in reference to the rising population of aging or aged Australians who remain active well past retirement. Around the English-speaking world, grey power describes different groups of politically active 'older persons' (see below). The US organization Gray Panthers celebrated their 40th Anniversary Year of Activism in 2010. One of their activities was to establish the Media Watch Observer's Report Form, which monitored the representation of older people and campaigned again ageism in the media. Part-forwhole euphemisms of this nature are comparatively rare; as outlined below, it is a far more usual strategy for forming dysphemisms.

A recent example of general-for-specific wording is third age, as in the 'Universities of the Third Age'. This expression was enthusiastically taken up during the 1980s and 1990s, especially by those who were in the business of putting positive spin on aging. It comes from Peter Laslett's influential book, A Fresh Map of Life: The Emergence of the Third Age, which looked at the challenges of an aging population in the world's developed countries. Laslett's point was that medical, social and economic changes had created a new 'third age' (first age = immaturity and dependence; second age $=$ maturity and independence; third age = personal fulfilment; fourth age = final dependence and death). The expression still connotes activity, vigour, freedom, control and achievement. Given that most people are unfamiliar with Laslett's work and the four ages, the 'third age' has come to stand for "old age", with "youth" and "middle age" being the two other ages. The problem then is how exactly to determine where middle age falls - is it $35,40,50$, or older? Age-related terms keep shifting around, much like the labels for those body parts speakers prefer not label (a phenomenon known colloquially in linguistics as 'genital flipflop'7). The taboo surrounding old age creates the same sort of instability (something I will return to below).

\footnotetext{
${ }^{6}$ Cf. references in Danat [1980: 486].

7 The loins, for instance, originally described the body part below the ribs and above the hips (the word is related to lumbar and lumbago). Other examples include the ambiguity of slang anatomical terms such as fanny, prat and tail, which all at some stage in their linguistic history have referred to both "buttocks" and "female pudendum" (and in the case of tail the "virile member" as well); cf. Burridge [2004: 226-228].
} 
Similarly, many euphemisms involve the straightforward substitution of conceptually related words that happen to have more pleasing connotations, as a way of dressing up reality. Expressions such as venerable and respected carry lofty associations that emphasize some of the positive aspects of the aging process - dignity of appearance, the deference that is commanded and so forth. Compare expressions such as veteran and elder statesman, that carry with them the prestige and seniority of someone who has seen long service in an occupation (in the case of veteran, typically the army). Many aged care facilities (another euphemism) now have lodge or manor in their titles, such as Manchester Lodge and Rosedale Manor. One sense of a lodge is that of temporary (typically holiday) accommodation, such as a ski lodge or hunting lodge. Perhaps the point being made here is that the current reality (the 'fourth age') is only short-term - a kind of stopgap along the path to another (better) place. Of course, lodges can also refer to the accommodation in parks or estates, and, like manors (the main houses or mansions on some property of significance), they have elevated associations.

When speakers overstep the mark, at some stage this sort of exaggerated usage turns into hyperbole (the antithetical strategy to understatement). The phrase past one's prime (where prime "best part, heyday" refers to physical beauty, professional ability etc. (compare over the hill) has given us prime-timer. This expression turns the original meaning of prime time on its head with the focus now on the opposite end of the age range - when the word entered English in the late 1400s (from Middle French printemps), it referred to "springtime, spring" and in the 1500s transferred figuratively to "the early part of youth". Political correctness of the 80s and 90s also has provided an exuberance of such expressions. Examples such as the chronologically gifted or the experientially enhanced might well have started off as satirical inventions (along the lines of follicularly challenged "bald" and specially nontall "short") but they have now been adopted by some politicians and health-care workers promoting 'successful aging', and also with enthusiasm by the groups of CGs or CGers (the "chronologically gifted") themselves.

\subsubsection{Distortion}

A common strategy for the creation euphemism is to mask the taboo topic by modifying the offensive expression in some way. One practice involves shortening; for example, the end-clipping of geriatric to produce geri. In professional contexts involving 'old age', we typically find that longer phrases have been turned into acronyms or initialisms, such as OAPs (< 'old Age Persons or Pensioners'), or from hospital slang COPS ( $<$ Crotchedy old Patients), LOMs (< Little old Men) and LOLs (< Little old Ladies). This sort shortening is anyway an earmark of professional '-eses' such as Bureaucratese and Medicalese, but it offers at the same time an effective form of verbal disguise. A speaker might even take simply the initial letter of the forbidden word - on the model of the ' $F$ ' word and the ' $C$ ' word we now have the ' $O$ ' word 'old' (and many others, including the ' $R$ ' word 'recession'). In writing, these might be fleshed out with non-lexical expressions such as asterisks or a long dash. This practice seems to be a usage reserved for the more severely tabooed expressions - both $o^{* *}$ (or $o-$ ) and the ' $O$ ' word tend to be jocular; compare the verbal play of zuppies (< Zestful upscale Persons in their Prime) and many woopies (< well off older Persons), on the inspiration of trendy neologisms such as yuppies (<Young Urban/Upwadly-moving Professional People), buppies (< Black Urban Professional People), maffies (< Middle-aged Affluent Folks). 
In the case of ellipsis, offending words are simply left out. The world of print renders something invisible with dashes, asterisks and suspension points (the email subject header ?\#*! is clearly dysphemistic). The spoken counterparts to these symbols are noises like $m h m$, er-mm. In the context of aging, examples of this kind of omission are not common, although there are plenty of contexts where references to age have now become taboo and are therefore excluded. For example, reactions against age discrimination in the work place mean that in some countries date of birth is no longer expected in a curriculum vitae - and selection panels who request the age of a job applicant are risking charges of ageism.

Where one word (or more) drops out, the result is a semantic shift as the sense of the full expression then transfers to what remains (e.g. fall from fall of leaves). For example, getting on leaves out full mention of the crucial in years or in life; the resulting verb has a range of positive senses including "advance, make progress" and "succeed, prosper" and alludes only very generally to old age. The expression senior citizen (itself a euphemism) is generally now abbreviated to senior. In comparison to senior citizen, which has been around longer, senior retains more positive associations to do with higher rank or standing (though, as discussed below, these too are waning).

Other grammatical structures offer further opportunities for omission. Certain construction types enable speakers and writers to leave out pieces of information and this can be used to great effect in creating euphemisms. For example, the year 1999 was 'The International Year of the Older Person'. The expression older person employs the comparative construction, but in this case with a missing conclusion (compare teenage slang old as "very old"). Generally speaking comparatives express difference along a scale, specifically the notion "more". However, without a standard of comparison provided, all it does is serve to blur the edges. Paradoxically, older then becomes not as old as old. The older person sometimes appears as the longer living or the longer lived. The heyday of these euphemisms was 1970s and in the United States there were several well-known attempts to relabel 'Departments of the Aging' as 'Departments of the Longer Living'. You might compare the fuller figure a euphemism used in the fashion industry. Advertising generally uses the cagey comparative to great effect; the fact that there is no standard of comparison always provides the advertiser with an 'out' (e.g. Our oranges are sweeter - sweeter than lemons, perhaps?). Elder is also the comparative of old (and once equivalent to older). It now refers to persons "superior in age and experience whose counsel is therefore sought and valued". In recent times, this has emerged as the preferred name for this group (elders, elder females, elder males); it has also supplied the backformation eld "old age".

The antithetical strategy to shortening is circumlocution (or long-windedness). This is included here under distortion because it involves the reconfiguration of the original expression, this time in a process akin to componential analysis. The senses of a taboo term are unpacked, each of the meaning components is listed and the resulting periphrasis functions as a euphemism, such as getting on in years. (It is this same process that turns doors into entry systems, toothbrushes into home plaque removal instruments and teachers into learning facilitators.) Under cover of words we can tip toe linguistically around any sensitive topics such as old age, and the more words the better. The motivation is also often to upgrade alternative nomenclature. Examples include: noteworthy for his/her character lines, to have seen better days, to pass three score years and ten, to be past one's prime, getting on a bit, of advanced years, of indeterminate age, living on borrowed time and full of years. Certain types of aged care facilities in the United States are now known as assisted living residences, assisted living facilities (ALFS) 
or senior congregate living communities. As various websites explain, this sort of care involves 'independent living in senior apartments (itself a nice euphemism!), with added custodial and medical care'8.

There are various other forms of distortion that renovate an offensive word. Though these don't figure strongly in the camouflage language for 'old age', they are sometimes playfully employed in the creation of jokey slang expressions. Phonological remodelling involves adjusting the pronunciation of words; an example here might be eld "old age", though it also a backformation of elder (compare heck < hell). Affixation adds of some kind of prefix/suffix/infix; for example, oldie and oldster (modelled on youngster). Blending includes portmanteau words of various kinds; for example, zoomer to describe the aging baby boomer (< boomer + zip, also playing on the verb to zoom "to go fast"). Reduplication repeats syllables or letters of words; for example, prime timer (compare, jeepers creepers for "Jesus Christ"). Alliteration involves sequences of the same sound, such as dentured dandy and rhyming (slang) such as brown bread "dead" (also hovis "dead" from a brand of brown bread), [old] pot and pan "old man" (compare Brahms [and Liszt] "pissed, drunk"). The secret languages described by Allan (this volume) show regular morpho-phonological changes of these kinds. Upp-Upp language, for example, inserts 'upp' between the onset and rhyme of each syllable: 'Very old' becomes vupperuppy uppold. Backslang reverses the letters (and inserts the occasional vowel to make the string pronounceable); hence, yrev delo.

\subsubsection{Internal and external borrowing}

There are many ways euphemisms can be created by the substitution of other terms. This can involve a type of internal borrowing from sub-varieties, such as jargon and slang, within the same language. Learned or technical terms provide ready-made euphemisms. Examples here might include: senesce "to age", senescent "growing old", caducity "old age" as well as specific labels such as septuagenarian "seventy-year-old" and octogenarian "eighty-year-old", which avoid spelling out the actual age of the person. This sort of terminology is overwhelmingly classical in origin, drawing especially on high-bred sources such as Latin and Greek. If not directly borrowed from prestigious jargons such as Medicalese, they at least smack of a specialist language. It is a euphemistic strategy that has been aptly dubbed by lexicographer John Ayto [1993] as the 'blind-them-with-science' school of euphemism.

The antithetical strategy is to use a colloquial rather than a learned term. As described earlier, slang terms such as grots "derelicts and alcoholics", crumbles "the frail and elderly at death's door" and vegetables "unresponsive or comatose patients" seem at first blush to be horribly callous, but are part and parcel of the survival techniques of those who have to deal with death and dying on a daily basis. The levity of slang expressions such as these makes the job easier to bear.

Most languages seem to have some euphemisms based on words or morphs that have been borrowed from another language. There is nothing like a lexical exotic to blur unpleasant reality and foreign languages such as French and Latin have been providing English with either fig leaves or dress ups for centuries. French has given us doyen (masculine) and (more usually) doyenne (feminine) to describe the most senior member

\footnotetext{
${ }^{8}$ For example: http://www.helpguide.org/elder/congregate housing seniors residential.htm [accessed $4^{\text {th }}$ May 2011].
} 
of a body of people; it nicely sidesteps the fact that the person is usually 'old'. Another notable example, also from the $18^{\text {th }}$ century, is un certain $\hat{g}$ e, the inspiration for the English equivalent a certain age just discussed. Again from the same era is passé. Like un certain âge, it has been used particularly of women who could be described as having passed their prime. The use of Latin terms provides Standard English with many euphemisms for bodily effluvia, sex and associated acts and bodily organs, and, as Allan (this volume) describes, until recently translations of taboo terms from exotic languages, and descriptions of taboo acts, caused an author to suddenly switch from English to Latin. In the context of aging, it figures more as the basis for the technical terms just discussed. But there is one clear example of a euphemism borrowed directly from Latin; namely, anno domini. Although usually meaning "the year of our Lord" (and abbreviated AD), the expression was co-opted to refer to "advancing age" or "the passing of years"; for example, 'My resignation is due to what we call the anno Domini clause, which has come into operation' (The Times 31 March 1921; cited in the Oxford English Dictionary).

\subsection{Dysphemisms}

Dysphemism employs most of these same strategies. For example, the same imagery that gives us euphemistic expressions such as a ripe old age and mature can also be used to offend, as in describing someone as overripe or run / gone to seed. Hyperbole can always be used to exaggerate the offense as in old fossil and shrivelled old git. Like insults generally, many of these expressions pick on the person's physical appearance and mental ability, character and their behaviour in order to degrade. For example, biddy, crone, granny, grimalkin, hag, harridan and witch all denote the older female with undesirable physical features or objectionable behaviour, as do expressions such as codger, coot, fogy, gaffer and geezer which depict older males in an unflattering way by ascribing aberrant behavior to them, especially the suggestion of antiquated notions (i.e. behind the times). Many of these started life as polite terms; e.g. 16 th century gaffer (probably originally a contraction of godfather) was a term of respect applied to elderly men of position; (note, it now also refers generally to men who work on a TV/movie set; hence gaffer tape).

There is, however, one significant difference in the two main types of X-phemism. Whereas (vague) general-for-specific euphemisms are commonplace, dysphemism is much more likely to employ a (blunt) part-for-whole strategy. Compare, tits for "breasts" versus euphemistic chest or figurative epithets like he's a prick versus the legalistic euphemism person for "penis". In the context of old age, expressions that focus, say, on the physical aspects of showing one's years are generally offensive; for example, wrinkled, toothless, rickety and so on. Notable exceptions are expressions such as grey and grey haired, which, as discussed earlier, are polite, at least for 'the older male'. Other differences between euphemism and dysphemism are predictable. The use of borrowed terms, circumlocution or technical jargon is usually dysphemistic when it is perceived by the audience to be befuddling gobbledygook.

\section{The Seven Ages of a Euphemism}

There are internal forces generally at work in language change that ensure the majority of euphemisms are doomed to be short-lived. One is semantic pejoration. Over time, words are much more likely to take on negative overtones than they are 
favourable ones. Perhaps, we are inherently pessimistic. We are more likely to look for the worst in things. We scold and disapprove far more than we applaud and admire. Bad news is always more interesting than good news. All this is reflected in the way words change (cf. Burridge [2010]). In this instance, euphemistic expressions become sullied by the disagreeable concepts they designate. This sort of chronic contagion relates more specifically to the low-key euphemistic expressions under sections 2.1 and 2.2. The second force is a form of linguistic 'routinization'. Through constant use, novel and exciting ways of saying things become everyday and mundane. Some areas of the lexicon are particularly prone to this; insults lose their wounding capacity, swearwords their pungency, slang expressions their vigour. With time, face-saving euphemisms lose their protective magic, and the more flamboyant or ostentatious expressions under sections 2.3-2.6 no longer grab our attention.

\subsection{Contamination - Gresham's Law}

Economics has Gresham's Law: Bad money drives out good. Sociology now has Knight's Law: Bad talk drives out good. Linguistics has the Allan-Burridge Law of Semantic Change: Bad connotations drive out good (cf. Allan and Burridge [1991: 22ff]; [2006: 243]) 9 . The effect of this law is that many euphemisms become tainted over time. As the negative associations reassert themselves and undermine the euphemistic quality of the word, the next generation of speakers grows up learning the word as the direct term. Jespersen [1905/1962: 230] describes this as 'the usual destiny of euphemisms' - the 'innocent word' becomes 'just as objectionable as the word it has ousted and now is rejected in its turn'. Hence, taboo areas of the lexicon perpetually generate narrowing and deterioration of meaning; Steven Pinker's [1997] 'euphemistic treadmill'.

In 1957 Charles Osgood and his colleagues provided psycholinguistic support for this process. Their now famous study outlines a technique, the 'semantic differential', for systematically (though subjectively) quantifying connotative meaning. People were asked to evaluate numerous words and phrases on a series of seven-point bipolar rating scales. The aim was to locate a concept in semantic space within three dimensions of attitude: evaluation (is the word good or bad); activity (is the word active or passive); potency (is the word strong or weak). Their research confirmed what we know from the behaviour of words over time: that there is a general tendency for any derogatory or unfavourable denotation or connotation within a language expression to dominate the interpretation of its immediate context.

In the case of 'old age', the pejoration can be rapid. As society's prejudiced perceptions foment, the euphemistic value is diluted and the negative connotations quickly reattach themselves, requiring the formation a new euphemism. Consider the

\footnotetext{
${ }^{9}$ The expression 'Gresham's law' is named after Sir Thomas Gresham, a $16^{\text {th }}$ century English financier who worked for King Edward VI. The law dates back to the 1850s when it was first used by economist Henry Dunning Macleod to refer to the tendency (when there is more than one form of money in circulation) for bad money to drive out good money. The application of Gresham's Law to language is not recent and the linguistic law should more properly be labeled Rawson's Law, or even Bernstein's Law of Semantic Change. Hugh Rawson referred to Gresham's Law of Language in the first edition (1981) of Rawson's Dictionary of Euphemisms \& Other Doubletalk. Even earlier, Theodore Menline Bernstein, journalist and former editor of The New York Times, outlined his second law of language (also based on Gresham's Law): 'Bad words tend to drive out good ones and when they do the good ones never appreciate in value sometimes maintain their value but most often lose in value whereas the bad words may remain bad or get better' (The Careful Writer 1965).
} 
deterioration of words such as senile and geriatric. Senile "belonging to old age" dates from the 1600s; Samuel Johnson's dictionary has entries such as 'a senile maturity of judgment', but the word soon started to deteriorate and, with the exception of disease names such as senile dementia, is now dysphemistic. Senility has suffered a similar fate, evident in Charles Lamb's now striking description 'he is yet in green and vigorous senility' (Essays of Eli, first published 1823); here the clash of senses renders the quotation extremely odd. Derived from the specialist term geriatrics (the branch of medicine / social science to do with the health of old people), the adjective geriatric started life in the 1920s also as a neutral description; though both the adjective and noun remain orthophemistic within medical jargon, in everyday usage they had become a contemptuous term by the 1960s. To date, the word senior, as in senior citizen, has perhaps not yet had time to acquire negative overtones (senior citizen first made an appearance in the 1930s), but it is a euphemism ripe for renewal. In Australia, the label seniors is still used in official contexts for the 50+ - but there are not many 50somethings who would want to be described as senior citizens or even seniors. The demeaning way in which modern society views aging and aged individuals generally guarantees that time will blow the cover of any euphemistic disguise, though it turns out not all degenerate to the extent of senile and geriatric.

\subsection{Routinization}

Despite Gresham's Law, some euphemisms are simply so fleeting that they never linger long enough to become unfit for use. Many of the expressions given earlier simply shuffled off the lexical coil before they had a chance to deteriorate: ultra-mature, dynamic maturity, seasoned, golden ager etc. were short-lived; few would have them as part of their active vocabulary these days. Speakers / writers constantly strive to enhance expression and supply new and exciting ways of communicating. This sort of emotional extravagance drives change at all linguistic levels, but especially the lexicon. In particular, it is the culturally potent words that fray the fastest. Many euphemisms involve slang, and the mark of slang is that it will quickly date. A study of student slang at the University of North Carolina Chapel Hill, showed that over a fifteen-year period fewer than $10 \%$ of the expressions had survived (McArthur [1992: 940]). That which is slang for one generation is either no longer in fashion for the next or becomes mainstream. In Grose's late $18^{\text {th }}$ Dictionary of the Vulgar Tongue, the majority of the slang terms appear very outdated; few are still in use. Eventually, slang expressions either stop being slangy by intruding into neutral style and becoming standard usage, or they simply drop by the wayside.

In the life of euphemism, wear and tear sees metaphorical links severed, imagery buried and expressions stripped of their force; times pushes these expressions below the level of consciousness. And while this may be good news for the face-saving euphemisms that seek to slip through the discourse unobserved, this is not the case if the function of a euphemism is to provoke, to inflate, to amuse or even to define the gang. These expressions will not want to take a back seat. The euphemistic turnover here is not because time has eroded the euphemistic cover necessarily, but because the imposition of routine and associated semantic-pragmatic loss has rendered the expression inconspicuous and unremarkable - it is the same tug-of-war that exists between routinization or idiomatization, on the one hand, and expressivity or creativity, on the other that drives many linguistic innovations (cf. Hopper and Traugott [1993] on grammaticization). 


\subsection{The longer-living euphemism}

In order to get a better understanding of the life span of a euphemism, let us leave 'old age' for a moment and consider briefly another area of social taboo; namely 'smells'. What is immediately striking about the words for those "substances which excite the membrane of the nose" is the asymmetry - English (and many other languages) have plenty of expressions to describe bad smells (such as stink, stench, reek, pong, niff) but few positive expressions (such as fragrance, and perfume) and few, if any, genuinely neutral ones. Even the term smell has a whiff about it - its derived adjective smelly certainly does. The shift from "neutral/good smell" to "disagreeable smell" is a typical path. Consider the following six nouns, ranging from those with the most disagreeable connotations to those with the most pleasing:
stench — the oldest of the group, first recorded in 893
stink - appears early as a verb "to emit a smell"; first recorded as a noun 1000
smell - appears first as a verb; later as a noun in 1300
odour - borrowed from French and entered English in the early 1300s
scent - borrowed from the French as a verb; first recorded as a noun in 1470
perfume - borrowed from the French; first recorded in 1667
aroma - also from French to refer to the smell of spices; dates from the 1800s

The longer the word has been in the language to refer to smelling, the more offensive its connotations; in short, the older the word, the more offensive the smell (stink and stench being the most foul). The most pleasing terms are French - odour, scent, perfume and aroma. French and Latin have long been a source of deodorizing language for English, but how fragrant these words are currently depends on how long they've been pressed into euphemistic service. Aroma and perfume as the most recent recruits are those most sweet-scented. Odour, as the oldest of the four, has already started to fester. The qualities of the euphemism diminish as the taboo sense declares itself.

However, the word age, and also its derived forms aging and aged, offer a different prospect for the duration of a euphemism. Age refers literally to "length of life, period of existence". When it entered English from French some time during the $14^{\text {th }}$ century it had already acquired the meaning "period of human life", but had soon narrowed to "the end part of life". As the lexicographer John Ayto neatly put it [1993: 228]: 'old age commandeers the terminology of an entire life, to try to roll back the years'. From the beginning of the $18^{\text {th }}$ century, the term age could refer quite generally to "old age", "senility". The following quotations from the Oxford English Dictionary illustrate: "Thus spoke the prudence and the fears of age' (Pope); 'the moroseness and peevishness of age' (Sears); 'Age is a time of peace, So it be free from pain' (Tennyson). Since the 1400s, aged has referred to the latter part of life, and since the 1800s so has aging. From birth we are aging and yet the meaning is always "old". These three terms have narrowed and in most contexts they would now be orthophemistic; in other words, the direct terms, being neither sweet-sounding, evasive, overly polite (euphemistic), nor harsh, blunt, offensive (dysphemistic).

There are several other success stories of expressions that have not only resisted contamination, but even retain their euphemistic qualities, sometimes over long periods. Elderly has been in the language since the early 1600s. Though its verbal veneer might now be wearing thin, it is not yet disrespectful. Since the early 1700 s, the expression $a$ 
certain age has been a polite and indirect way of referring to a woman's age when she is no longer young (the Oxford English Dictionary suggests somewhere between forty and sixty). In other domains, there are also some remarkably durable euphemisms: to sleep with "have sexual intercourse" has been in use since the $10^{\text {th }}$ century; to lose "be deprived (of someone) by death" since the $12^{\text {th }}$ century; pass away / pass since the $14^{\text {th }}$ century, deceased, departed and no longer with us "dead" since the $15^{\text {th }}$ century. Clearly, familiarity doesn't always breed contempt. So why are these euphemisms still with us, and how did they escape the corrosion of expressions such as geriatric and senile?

McGlone, Beck \& Pfiester [2006] argue that familiarity and ubiquity confer 'pragmatic stealth and mindlessness-inducing qualities' (p. 279) on a euphemism. In contradiction to the contamination argument, they claim that conventionality will in fact enhance, not diminish, the face-saving capacity of a euphemism.

Reductions in the cognitive capacity the expression recruits in turn lead to a diminution of its salience in discourse (McGlone, Glucksberg, \& Cacciari, 1994; Schwanenflugel, 1991). In contrast, less familiar expressions make greater demands on attentional capacity. By violating the idiomaticity maxim, they prompt addressees to devote a greater share of their cognitive resources to interpreting them and inferring the speaker's motives for flouting the maxim (Clark, 1979; Grice, 1975; Searle, 1975). Thus less conventional euphemisms call attention to themselves in a way that highly conventional euphemisms avoid. (p. 266)

It stands to reason, that conventionality enables expressions to be processed in a mechanical fashion; it is one of the reasons that frequent and highly irregular forms such as go-went escape the powerful regularizing forces of analogy (cf. Bybee [2006], [2008] on the effects of repetition). Words of high frequency are easier to access for speakers and hearers; they require less cognitive effort. And, as earlier described, time will always strip away the novelty and vividness that invite interpretation of an expression. Some familiar euphemisms may well remain polite over long periods precisely because they come to offer routine and unexciting ways of indirectly mentioning taboo topics. Yet familiarity effects cannot provide the whole story here, since these expressions have to survive in the first place in order to become routine.

The survey carried out by McGlone, Beck \& Pfiester revealed a correlation between familiarity and politeness; participants judged some very familiar face-saving euphemisms such as go to the bathroom/restroom and pass away as more polite than less usual expressions such as spend a penny and jump the last hurdle. While the high politeness ratings of the familiar euphemisms listed in their study seem uncontroversial, few of these expressions form part of the meaningful euphemistic vocabulary of modern-day English speakers; e.g. powder one's nose, do one's business, heed nature's call, in a better place, crossed the river, solid elimination. Evacuate one's system might be a familiar and polite way to refer to "expelling one's stomach contents" but it is hardly everyday. Those from the list that remain in use today (such as go to the bathroom/restroom and pass away) show a high level of abstraction. They have in common that they allude to taboo topics in a very remote way; their association lacks any sort of precision, allowing them to remain unobtrusive and to sneak through the discourse unscathed. Similarly, the generality of age, aged and aging enables these to slip under the radar; the comparative origins of elderly continues to throw up smoke by providing the hedge "somewhat aged" (compare older and elder).

Nonetheless, it remains a fact of linguistic life that most euphemistic expressions deteriorate over time and often spectacularly. To my mind, the longevity of these 
euphemisms remains an anomaly, in the manner of those atypical slang expressions that manage somehow to retain their original energy, sometimes over centuries. Grose's Dictionary of the Vulgar Tongue offers a rich copulatory lexicon; a handful of expressions (such as shag and screw) continue to pack a punch. When the Sex Pistols composed their memorable lyrics Friggin' in the Riggin', they probably didn't realize just how old this figurative language was; the sexual sense of the verb to frig goes back to the $16^{\text {th }}$ century and rig(ging) has a convoluted sexual history dating back almost as far. The shelf life of some euphemisms remains a mystery.

\subsection{Conceptual Change}

In challenging contamination as an explanation, McGlone, Beck \& Pfiester [2006] look to changes in the concept itself to account for the 'euphemism treadmill'. 'When technological or scientific advancement alters the way society conceives of such a topic, conceptual innovation is the engine of euphemism turnover, not familiarity' (p. 278). For example, the trigger behind the shift in expressions for "the facility for disposing body waste" (water closet > latrine > toilet > bathroom) has been transformations to the fixture itself (e.g. increase in the size and composition). While innovations in science and technology have repercussions for the lexicon, my objection here is the fact that changes in a referent typically do not render its expression obsolete. The process is more usually one of subreption ('old words in a new world'), and it is a significant force behind meaning shift. The advent of motorization has brought with it remarkable changes for words such as car, tyre, lorry and truck; yet the terms remain. The modern-day dashboard is a far cry from the board on coaches to stop the driver getting covered in mud and dung. The visor on a knight's helmet has transformed into the shield of the modern-day crash helmet (or in North America the peak of a cap). The verb write derives from a Germanic word meaning "to scratch, carve" and goes back to the time where people scratched runes into wood or rock. We continue to write - and with a pen (< "feather"). Clearly, the world changes, but unless taboo is involved, the expressions will typically adapt by extending or shifting their meaning. Conceptual change in science and technology is not responsible for the displacement of euphemisms.

In social, cultural, and political domains, however, it in might well have a place, in particular if the euphemisms are deliberately provocative or attention-seeking - societal shifts always have linguistic repercussions, especially for the lexicon. PC-driven changes, for example, seek to make a point and are a form of natural linguistic evolution in the face of more general sociocultural change. In many places the terms married and de facto spouse only include those relationships that can be sanctioned by legal or quasi-legal marriage. The newer terms such as partner sidestep that issue, and are therefore representative of relationships other than heterosexual. The term queer is now preferred by many because it is seen to include groups such as bisexuals and transsexuals, which the terms gay and lesbian do not. As earlier mentioned, PC euphemism is a form of public action; by drawing attention to itself, it forces us to sit up and take notice. As is always the case with renaming initiatives, however, such labels are controversial. The battle is often as much about who has the power to name as the naming itself; who decides the identity of a group and its desires and interests. 


\section{Language change and the special case of naming taboo}

People always grow up like their names. It took
me thirty years to work off the effects of being
called Eric. If I wanted a girl to grow up
beautiful Id call her Elizabeth.
(Letters of George Orwell - originally Eric
Blair; cited in Crystal [1995: 148])

Throughout history people have attributed supernatural powers to names and naming forms a special case of word taboo (Allan and Burridge [2006: Ch. 9]). There are naming taboos observed by people undertaking hazardous pursuits such as mining, hunting and fishing, and they involve, for example, taboos on the names of dangerous animals. These practices are motivated by fears comparable with those on death and disease and people use similar strategies to avoid calling down malfeasance upon themselves. Consider the Ukrainian proverb Pro vovka pomovka a vovk u khatu "One speaks of the wolf and it runs into the house" [lit. about wolf talk and wolf into house] and the English proverb speak of the devil and he comes running.

As an interesting illustration of name magic, take the word for "tongue" in the IndoEuropean languages. Since all humans have tongues, we assume there must have been a word for this body part in the proto language. Yet, as historical linguist, Hans Heinrich Hock points out [1986: 305], we cannot reconstruct one, or at least we cannot reconstruct the shape of it. Particularly problematic is the initial consonant, which in itself is noteworthy, given that the beginnings of words are typically the most stable and therefore the most reconstructable when it comes to recreating lost Indo-European forms. So why is it not possible to reproduce the word for "tongue" here? Many of the apparent cognate words in the related daughter languages have undergone peculiar and irregular sound changes - sounds swap places or have changed inexplicably (sometimes contaminated by the semantically related verb "to lick"). The reason lies in the irrational forces of taboo. As Hock points out, the tongue is the organ of speech, therefore it was imbued with magical powers, like speech itself - speech made it possible to name things or people and by naming them to have power over them. The word was therefore subject to the same kind of tabooistic magic as the words for the supernatural and other kinds of dreadful phenomena.

Not surprisingly, personal names (that is, true names) have been or still are taboo among peoples in many parts of the world. This is another fear-based taboo. Sorcerers can do harm to a person if they are in possession of that persons true name (cf. Allan and Burridge [1991], [2006]). A name is regarded as a proper part of the name bearer, not just a symbol but the verbal expression of his or her personality. Thus in many languages, a name is an inalienable possession and is assumed to be an inseparable part of the body. Other properties of personal representation such as mind, spirit, soul, shadow and reflection are often treated in the same way and this can have repercussions for the grammar (cf. Chappell and McGregor [1997]). Because true names are so closely associated with their name-bearer as to be a proper part of him/her, in some societies (for example, in traditional Austronesia) there are strict taboos preventing two living persons from going by the same name. Furthermore true names are often secret, rendering euphemistic names necessary for public naming and addressing. In many places, names of the dead are (or were until recently) taboo. Sometimes the ban extends to those personal names that the dead person may have given to others. Violations of 
such taboos are believed to cause misfortune, sickness and death; they may also cause offense to living descendants.

Naming taboos can have major effects on the ordinary vocabulary of some languages, because the personal names are common words or derive from common words. In this way, naming taboos can be extended to become word taboo. Simons [1982], for example, describes how of a sample of 50 Austronesian languages which are known to have some sort of naming taboo, 25 of these have a name taboo that extends into common word taboo. A further 18 have a taboo whereby words even resembling the tabooed names are taboo themselves. On Santa Cruz (part of the Solomon Islands), where there is a taboo against using the name of certain affines, names consist of a common word, normally with a gender-marking prefix. Thus if a man's mother-in-law is called ikio ( $i$ - "prefix to female's name", kio "bird"), he cannot use the common word kio to refer to birds. The effect of this is that something like $46 \%$ of the everyday vocabulary is potentially taboo for some people on Santa Cruz; on the island of Malaita, this figure is as high as $59 \%$.

Euphemisms are thus created via the methods outlined earlier: semantic shifts of existing words, circumlocution and also phonological modification. Sounds turn up in odd places; they mutate unexpectedly. Words are often funny-looking. (Here you might compare the situation where the urge to swear in polite company drives an English speaker to spontaneously change shit to shite or fuck to fudge.) There is also a high rate of borrowing, even among core vocabulary items that that are not generally borrowed. Under normal circumstances why would speakers need to take kinship terms or pronouns from another language? It is precisely these established common-usage words that historical linguists trust when it comes to establishing genetic relationships and reconstructing lost stages of languages (though in the case of pronouns, phonological wear and tear is such that the surviving fragments may not reveal much). Yet, in this context even basic vocabulary of this kind cannot be relied on to remain stable. Extensive borrowing and taboo-induced remodelling make it difficult to determine the chronology of linguistic changes that have occurred. Irregular sound shifts have the effect of accelerating vocabulary differentiation between genetically related languages and can create a false impression of long divergences, in some cases even hiding genetic connections. Take the following vocabulary correspondences between Kwaio and Lau (also Solomon Islands) provided by Simons [1982: 168].

$\begin{array}{lll}\text { Kwaio } & \text { Lau } & \text { Meaning } \\ \text { gani } & \text { dani } & \text { day, daylight } \\ \text { logo } & \text { rodo } & \text { night, dark } \\ \text {-ga } & - \text { da } & \text { 3rd possessive } \\ \text { aga } & \text { ada } & \text { look, see } \\ \text { gamu } & \text { damu } & \text { K. chew; L. smack lips } \\ \text { guigui } & \text { duidui } & \text { vinegar ant } \\ \text { ugu } & \text { udu } & \text { a drop of water } \\ \text { age } & \text { ade } & \text { do, happen } \\ \text { nagama } & \text { madama } & \text { moon }\end{array}$

Here Kwaio's tendency toward changing $d>g$ is an example of recurring irregular sound change that is so common that it appears a regular change. However, there is no conditioning factor for this regular $g: d$ correspondence, and Kwaio has doublets for gani, gamu and guigui which are identical with the Lau forms. The explanation for this kind of 
common irregular sound change is to be found in the capricious mechanisms of word tabooing, not in regular inheritance from the proto-language.

Aboriginal Australia offers another perspective of the effects of naming taboo on vocabulary. In many traditional Australian Aboriginal communities, any kind of vocabulary item, including grammatical words, can be proscribed if it is the same as, or phonetically similar to, the name of a recently deceased person. Replacement vocabulary is created using synonyms from the language's own repertoire (or from an auxiliary repertoire of respect language), semantic shifts of existing words, compounding, circumlocution, borrowing from a neighbouring language, and in some cases a hand-sign or gesture. Some languages have special vocabulary items to be used in place of proscribed words, sometimes a kind of 'whatsitsname / whatchamacallut' word or one that is reserved especially for the purpose of name-avoidance. For example, in some Kimberley languages in the north of Western Australia, those whose personal names have been tabooed are addressed as nyapurr "no name"10.

Striking illustration of this involves the changes to the first person pronoun in some dialects of the Western Desert. On the death of a man named Ngayunya, these languages replaced the pronoun ngayu "I/me" with nganku. Subsequently, this term was itself tabooed and replaced by either English mi or by ngayu borrowed back into the language from dialects where it had never been tabooed (cf. Dixon [1980: 29]). This shows that the taboo on a word may cease after some years have passed, allowing it to come back into use. This recycling is one of the very few ways in which a former tabooed item can itself become a euphemism and is another dent in the notion of absolute taboo. Linguists Alpher and Nash (1999) claim that, where the history is clear, such cases of deathtabooing have always proved to be temporary ${ }^{11}$. The taboo on a word may cease after some months, or one or two years have passed, allowing the word to come back into use. Moreover, it appears that there is no absolute prohibition on mentioning the name of a dead person. Vocabulary is taboo for only those people who stand in a certain relationship with the dead person. Locals can continue to use the taboo forms out of earshot of the bereaved family.

Given the experience of Aboriginal Australia, we have to allow for the fact that the effects of taboo on vocabulary might occasionally be overstated. Understandably, in the fieldwork context it would be natural, the polite thing to do, for an informant to provide the outside field-worker with the avoidance terms. This could well give an exaggerated impression of severity of the taboo and the extent of the vocabulary replacement rate. There might even be a bit of embellishment on the part of the field worker (exotification of the other), and perhaps also on the part of the informant seeking to make a deeper impression on the naïve onlooker. However, even allowing for exaggerated accounts, it is clear from the endeavours of historical linguists that this kind of naming taboo can have a profound effect on the vocabularies of these languages. Many researchers working on languages in Australasia and the Pacific have noted the difficulty of identifying regular sound correspondences between cognate (or related) forms ${ }^{12}$. But of course, these speech communities are not closed to innovation either, and they are certainly not closed to importing cultural elements from the outside. As earlier described, taboos and attitudes towards taboo violation do change over time and many

\footnotetext{
${ }^{10}$ William McGregor pers. com. Details of these strategies are also provided in Dixon [1980], Nash and Simpson [1981], Alpher and Nash [1999].

${ }^{11}$ Cf. Alpher and Nash [1999: 9]; they also cite Black [1977: 56-58].

${ }^{12}$ Cf. discussions in Holzknecht [1988]; Keesing and Fifi?i [1969]; Ray [1926]; Wurm [1970]; Dyen [1963].
} 
of these old taboos are now disappearing, having been affected by the spread of Western ideas.

\subsection{The current western perspective on naming}

There are probably few Westerners today who would admit to still believing in magic and the supernatural powers of names. And yet, the practice of onomancy (interpreting names as omens) is still alive and well. Think of the occasional punter at the track who selects a horse simply because its name has some special significance. Perhaps it links with a recent event or significant person. The keywords 'name' and 'magic' typed into any web search will uncover instructions on how to cast a spell on someone using their true name, how to find the luckiest name for a new-born baby, how to find the perfect sole mate (using names and numerology to compute the love, sex and intellectual compatibility of partners). There are also sites that will assist in finding the meaningful anagrams of names and ways of interpreting these to define one's destiny.

Even those who pooh-pooh this kind of superstitious carrying on manifest forms of behaviour that strongly suggest a belief in some sort of magical relationship between a name and the individual who bears it. Many experience difficulty when they have to say out loud their own name; this is not confined to young children. Is it vestigial superstition at revealing one's real name, or is it simply that names are so inextricably bound up with our innermost selves that we feel embarrassed to reveal such an intimate detail to strangers. When someone misspells our name, they touch a soft spot. From a very early age children learn the effectiveness of name-calling, often upsetting their peers by focusing on physical aspects (square eyes, fatty) but also playing with aspects of their names (changing Burridge to Porridge). We are our names and insulting names do hurt.

Another aspect to name magic is the way people react to the personal names of strangers. Perhaps its because many English names carry sound symbolic associations. Research by Cutler, McQueen and Robinson [1990], for example, reveals that quintessential male names are short (often single syllable) and end in a stop consonant, while female names are typically longer, involve sonorous consonants and often a strong high front vowel. Of course, there is also the fact that names come and go. Any fashionable name (such as Jason and Kylie) would reveal something of the age of a person. The fact that there are also traditional names (such as Susan and John) and novelty names (such as Sky and River) may also help us assess the attitudes of the name bearer, or perhaps more so those of the name giver. But studies carried out on the reactions of speakers to names also reveal that many of us go beyond this and actually do link names with certain personalities (cf. Dunkling [1977]). It is all part and parcel of our general stereotyping behaviour. Certain names make us recall the personality of individuals that have that name. The name then somehow seems to fit that personality: Marys are quiet, Davids are strong, Kylies are sexy and so on. When we encounter that name in a stranger, it generates a certain expectancy. It becomes one of the clues we use to access information about that persons social background or personality. Such stereotypes can be positive, negative, accurate or completely wrong-headed, but they are all of them selective. If speakers have come to associate certain personality traits with a certain name, when they encounter a person with that name, then they will see what they want to see. The features they take note of will be those that confirm expectations. These will overshadow other features and become the main characteristics of that person. In fact, studies of stereotyping show that people even go beyond the 
information that they are given. They see features that are not there and fail to see the ones that are.

The significance of naming in our society shows up in other ways. Ours is a culture that promotes personal names. Name-dropping is believed to give us social clout. People dispose of their names and adopt new ones to promote a better public image. People can even sell their names, as when someone endorses a commercial product. Those that buy the item expect to pay more to have the name inscribed on the goods. We have numerous phrases such as make a name for oneself; have a good name; bring ones name into disrepute; clearing ones name and so forth. Personal names can also lose their capital letter and enter the general lexicon as household words. There are the usual eponyms such as cardigans and sandwiches from the Earls of Cardigan and Sandwich. English has amassed more than 35, 000 of these expressions (Trahair [1990: 9]), but even more telling are the eponymic phrases that arise spontaneously in everyday language. Most are short-lived, it is true, but their pervasiveness speaks to the value of names. One memorable front-page headline of Melbourne's Age Newspaper reads: "Freed, Theophanous does a Pauline Hanson" (February 6, 2004)13.

All this ostentation appears in striking contrast to the behaviour of those in societies where there are strict taboos on naming and where true names remain secret. How different our media conscious $21^{\text {st }}$ century seems, where everyone is out there striving to be a name. And yet what we see here is simply a different side of the same coin. Whether they are revealed or concealed, names are highly charged vocabulary items they have power and mystique.

\section{Summing up taboo and language change}

In a striking example of scholarly squeamishness, it has only been relatively recently that the effects of taboo on language development have really made an appearance in the mainstream linguistics literature. Anyone wanting to know about taboo and language would have been compelled to seek out specialist anthropological accounts or what were assumed to be vaguely disreputable journals such as Maledicta. In the name of decency and decorum, discussions of taboo, even within historical linguistic textbooks, focused on remote examples involving primitive word magic and taboos on dangerous animals. The following account of taboo was fairly typical for the time:

Words may cease to be used by a speech community due to the development of a taboo. A taboo word is one which has come under prohibition, usually because of the sacred status of the reference of the word in question or because of fear inspired by the referent. When taboos develop, some other word or phrase, usually a descriptive term, is generally called upon to replace the forbidden word. The Germanic word for 'bear' (and the English word bear itself) is related to the word brown and originally meant 'the brown one'. The Russian word for 'bear' is medved', originally meaning 'honey-eater'. Neither the Germanic nor the Slavic languages have retained a reflex of the PIE [=Proto-Indo-European] root * rkso- that has survived in the southern IE

\footnotetext{
13 Pauline Hanson is a controversial figure in Australian politics. On 20 th August 2003 she was convicted electoral fraud and sentenced to three years imprisonment for falsely claiming that 500 support group members were genuine paid up members of her party One Nation. The expression to 'do a Pauline Hanson' alludes to the fact that on November 6 2003 the appeal court quashed and set aside her conviction - she was then freed from prison. The headline here refers to the release from prison of disgraced former MP, Andrew Theophanous.
} 
languages [...] In Ancient Greek the word drakôn 'the seeing one' replaced the earlier word for 'snake', which was completely lost from the Greek vocabulary.

(Jeffers \& Lehiste [1979: 135])

Any student of Linguistics was left with the impression that taboo embraced little more than ancient naming bans on wolves, weasels and brown bears. If modern western obscenities cracked a mention at all it was in coy reference to the indelicate connotations of words such as leg and thigh (Anttila [1989 (1972): 139]).

Yet, clearly those who study continuity and change in language have much to discover by delving into the unmentionable. Taboos, whether they be the so-called absolute taboos of Austronesia or the social taste constraints of Western-style taboos, are an enormously important force behind language change through (1) word loss (2) meaning shift of terms already in the language (via metaphor, general-for-specific, internal borrowing and so on), (3) deliberate modification of existing terms, (4) external borrowing. Word tabooing processes act as some kind of linguistic wild card and militate against the operation of regular predictable change. Consequently, they can play havoc with the conventional methods of historical and comparative linguistics, which operate on principles such as the regularity of sound change, the non-borrowability of core vocabulary and the non-existence of true synonyms. Taboo even undermines one of the very cornerstones of linguistics; namely, the arbitrary nature of the word. The fact that there is no necessary and no natural connection between the form of a word such as rose and its meaning "beautiful fragrant flower" is what gives linguists their license to compare languages they suspect are genetically related and (via procedures like the comparative method) to reconstruct lost linguistic stages. Yet, when it comes to taboo, the arbitrariness falls away and language users behave as if there were a very real association between sound and sense.

There exists plenty of linguistic evidence for the emotional quality of the literal descriptors of taboo topics. Even across languages, these words are able contaminate others, bringing down innocent bystanders that just happen to sound similar (e.g. the demise of coney "rabbit" and feck "efficiency" in English). Moreover, taboo senses have a saliency that dominates and frequency kills off all other senses of any language expression recruited as euphemism; those that escape this contamination have special properties. Psychological and neurobiological research even supports the fact that we process taboo language differently from other language, with considerable differences with respect to recall and recognition - forbidden words are in-built, hard-wired into the deep limbic systems of our brains (cf. Allan and Burridge [2006: Ch. 10]). It is the sociocultural setting that creates obscenity and gives it meaning. As the mother of a young Touretter once characterized the vocalizations of her daughter: 'Society shapes the noise that is made'14. Whether it is a matter of naming dangerous animals, uttering four letter words, striking a saucy trope to arouse or modest metonym to conceal, language users are aware of the potency of these expressions. Modern speakers of English share with their ancestors a profound respect for the close relationship between word and meaning and this remains a powerful motive for language change.

\footnotetext{
14 Taken from a web forum on coprolalia, maintained by the Department of Neurology at Massachusetts General Hospital; $\quad \underline{\text { http://neuro-www.mgh.harvard.edu/forum 2/TouretteSyndromeF/5.7.997.16PM }}$ Causesforcopr.html [Accessed October 2004, though no longer in available].
} 


\section{Bibliography}

AdAMS Phillip and Newell Patrice, The Penguin Book of Australian Jokes, Ringwod, Victoria: Penguin, 1994.

Allan Keith and BuRRIDGE Kate, Euphemism and Dysphemism: Language Used as Shield and Weapon, New York: Oxford University Press, 1991.

ALLAN Keith and BURRIDGE Kate, Forbidden Words: Taboo and the censoring of language, Cambridge: Cambridge University Press, 2006.

Allan Keith and BurRIDGE Kate, "Swearing and Taboo Language in Australian English", in Peters, Pam, Collins Peter and SMITh Adam (eds) Comparative Grammatical Studies in Australian and New Zealand English, Amsterdam: John Benjamins, 2009.

ALPHER Barry and NaSH David, "Lexical Teplacement and Cognate Equilibrium in Australia", Australian Journal of Linguistics Vol. 19 (1), 1999: 5-56, 2009.

ANTTILA Raimo, Historical and Comparative Linguistics, Amsterdam: John Benjamins, 1989 [1972].

Ayto John, A Dictionary of Euphemism, London: Bloomsbury Press, 1993.

BLACK Paul, "Lexicostatistics and Australian Languages: problems and prospects", in TRYON Darrell and WALSH Michael (eds), Boundary Rider: Essays in Honour of Geoffrey OGrady (Pacific Linguistics C-136), Canberra: Australian National University, 1997: 51-69.

BöRJARS Kersti and BURRIDGE Kate, Introducing English Grammar, London: Hodder Headline Group, 2010.

BURRIDGE Kate, Blooming English: Observations on the roots, cultivation and hybrids of the English language, Cambridge: Cambridge University Press, 2004.

BURRIDGE Kate, Gift of the Gob: Morsels of English language history, Sydney: HarperCollins [ABC Books], 2010.

BURRIDGE Kate and ALLAN Keith, "The X-phemistic Value of Romani in Non-Standard Speech", in MATRAS Yaron (ed), The Romani Element in non-standard Speech, Wiesbaden: Harrassowitz (Reihe: Sondersprachenforschung 4), 1998: 29-50.

ByBEE Joan, "From Usage to Grammar: The mind's response to repetition", Language Vol. 82 (4), 2006: 711-733.

BybEE Joan, "Mechanisms of Change in Grammaticalization: The role of frequency", in JoSEPH Brian D. and JANDA Richard D. (eds), Handbook for Historical Linguistics, 2008: 602-623.

ChAPPELl Hilary and MCGregor William (eds), The Grammar of Body Parts, Berlin: Mouton de Gruyter, 1997.

CorbYn Charles Adam, Sydney Revels (the Eighteen-Fifties) of Bacchus, Cupid and Momus; being choice and humorous selections from scenes at the Sydney Police Office and other public places, during the last three years, [Presented by Cyril Pearl] Sydney: Ure Smith, 1970 [1854].

Crystal David, The Cambridge Encyclopedia of the English Language, Cambridge: Cambridge University Press, 1995.

Crystal David, Language Play, Harmondsworth: Penguin, 1998.

DanAT Brenda, "Language in the Legal Process", Law and Society Review, Vol. 14, 1980: 445-564.

Dixon Robert M. W., The Languages of Australia, Cambridge: Cambridge University Press, 1980.

DunKLING Leslie Anne, Whats in a Name?, Sydney: Rigby Ltd, 1977. 
DYEN Isidore, "Lexicostatistically determined borrowing and taboo", Language Vol. 39 (1), 1963: 60-66.

EPSTEIN Joseph, "Sex and Euphemism", in EnRIGHT D. (ed.), Fair of Speech: The Uses of Euphemism, Oxford: Oxford University Press, 1985: 56-71.

GoRDon David P., "Hospital Slang for Patients: crocks, gomers, gorks, and others, Language in Society, Vol. 12, 1983:173-185.

GreEN Jonathan, Words Apart, London: Kyle Cathie Limited, 1996.

GRoSE (Captain) Francis, Dictionary of the Vulgar Tongue, London, 1881 [1783].

HallidaY Michael A. K., Language as a Social Semiotic, London: Edward Arnold, 1978.

Hоск Hans H., Principles of Historical Linguistics, Berlin: Mouton, 1986.

HolzKNeCHT Susanne, "Word Taboo and its Implications for Language Change in the Markham Family of Languages", PNG, Language and Linguistics in Melanesia, Vol. 18, 1988: 43-69.

JAMET Denis, "Euphemisms for Death: Reinventing Reality through Words", in SoRLIN Sandrine (Ed.), Inventive Linguistics, Montpellier: Presses Universitaires de la Méditerranée, 2010: 173-187.

JEFFERS Robert J. and LEHISTE Ilse, Principles and Methods for Historical Linguistics, Cambridge: MIT Press, 1979.

JESPERSEN Otto, Growth and Structure of the English Language, Oxford: Basil Blackwell, 1962 [1905].

KEESING Roger M. and FIFI?I Jonathon, "Kwaio word tabooing in its cultural context", Journal of Polynesian Society, Vol. 78, 1969: 154-177.

LASLETT Peter, A Fresh Map of Life: The Emergence of the Third Age, London: Weidenfeld and Nicolson, 1989.

LOFTUS Elizabeth F., "Leading Questions and the Eyewitness Report", Cognitive Psychology, Vol. 7, 1975: 560-572.

LofTus Elizabeth F., Eyewitness Testimony, Cambridge MA: Harvard University Press, 1979.

Milwood-HaRgRave Andrea, Delete Expletives?, Broadcasting Standards Commission, 2000.

NASH David and SIMPSON Jane, "No-name' in central Australia”, in MASEK Carrie S., HENDRICK Roberta A. and Miller Mary Frances (eds), Proceedings on Language and Behavior, Chicago: Chicago Linguistics Society, 1981: 165-177.

OsGood Charles E., George J. SucI, \& Percy H. Tannenbaum The Measurement of Meaning. Urbana: University of Illinois Press, 1957.

MCARThur Tom (ed), Oxford Companion to the English Language, Oxford: Oxford University Press, 1992.

Pinker Stephen, How the Mind Works, New York: W. W. Norton, 1997.

RAY Sidney H., A Comparative Study of the Melanesian Island Languages, London: Cambridge University Press, 1926.

ScuTT Jocelynne A., "Vilifying Women on the Football Field":

http://www.philcleary.com.au/afl racism football scutt.htm, 2002 [Accessed October 2004].

Simons Gary F., "Word taboo and comparative Austronesian linguistics", in HaLIM Amran, CARRINGTON Lois and WURM Stephen A. (eds), Papers from the Third International Conference on Austronesian Linguistics, Vol. 3. Accent on Variety, Canberra: Pacific Linguistics, 1982: 157-226.

TraHAIR Richard, Whats in a Name? An Australian Dictionary of Eponyms, Melbourne: Oxford University Press, 1990. 
TuiTE Kevin and Schulze Wolfgang, "A Case of Taboo-motivated Lexical Replacement in the Indigenous Languages of the Caucasus", Anthropological Linguistics, Vol. 40 (3) 1998: 363-383.

WURM Stephen A., "Austronesian and the vocabulary of languages of the Reef and Santa Cruz Islands - a preliminary approach", in WURM Stephen A. and LAYCOCK Don C. (eds), Pacific Linguistic Studies in Honour of Arthur Capell, 1970: 467-553.

WyLd Henry C., A History of Modern Colloquial English, Oxford: Blackwell, 1936 [1920]. 